\title{
Gender-Based Approach to the Preparation of Young People of Tuva for Family Life
}

\author{
Aldynai V. Seden* \\ Tuva State University \\ 36 Lenin Str., Kyzyl, 667000, Russia
}

Received 14.08.2014, received in revised form 24.08.2014, accepted 06.09.2014

\begin{abstract}
The marriage of the tuvinians was considered to be mandatory for every person, for extramarital relations were viewed with disapproval. Tuva families were large, differed stability, and divorces were rare due to the economic and moral reasons. Currently, serious changes have occurred. An increasing number of divorces changed the attitude to it in the public consciousness, it becomes commonplace. Changed premarital behavior of young people: do not operate the traditional installation on premarital chastity. When the whole evolution of the relations between the sexes in the direction of democracy, the tradition of inspiring young people to the marriage for the sake of compliance with customs. In Tuva remains stable orientation of the company to the marriage. For students it is very important "to have a husband (wife)" (57.4 per cent), "have children" (86,3\%).

About $70 \%$ of young people would like to live separately from their parents, which entail both positive and negative moments. On the one hand, the young family before gaining the independence, the responsibility, the easier it is in the process of adaptation of young spouses to each other. But, on the other hand, the young family is deprived of the systematic assistance of parents, which they need, especially in the period of the birth of the child. Violated in this case and constant communication with the grandfather and grandmother, which positively affects the grandchildren. Changing the age of entry into marriage and the very model of a traditional marriage. Increasing the birth of a child outside of marriage. The company was tolerate as to single mothers, as well as to divorce in families with underage children. Spread marital cohabitation. The birth rate in the republic keeps the positive dynamics, although there was observed a reduction in the number of large families. More than half of the students of both sexes consider that the conclusion of a marriage should be with their peers in the range of 21 to 25 years.
\end{abstract}

Keywords: marriage, family, national psychology, Tuva.

Research area: History.

Marriage among the Tuvans was considered to be mandatory for every person. Old virgins and old bachelors were not respected, and were considered to be not reliable, bad people. An unmarried girl over the age of 20 was already "an old maid", she was treated as inferior, with physical and other shortcomings. Father with daughter bride proverb calls the rich: "...would be daughter - in-law found". (Dorzhu, p.194). Young people, who are closer than the fifth generation, are considered relatives, therefore marriages between them are banned. Parents tried to ensure that their

(C) Siberian Federal University. All rights reserved

* Corresponding author E-mail address: aldynaseden@yandex.ru 
daughter gets married with a person from another tribe, like aals, summons, kozhuns, although the majority of marriages were of a local nature", i.e. were concluded between representatives of seoks that are located geographically close to each other (Dorzhu, p.195). Dear daughter-in-law as a continuer of family of the husband. Observance of the custom of the courtship was required, which consisted of three successive multi-temporal stages. This popular wisdom comes out of that enormous importance that provide marriage and family, especially in the past when people married for life. Therefore, the moment of choosing a future husband was crucial. The wedding was preceded by pre-nuptial ceremonies, an important component of which was the ritual of the youth fellowship. In choosing a marriage partner the girl was trying to find the chosen one, that would be her liking, young men longed for a helpmate and the mistress of the Yurt. valued prettiness, the ability to win a man's fertility. The system of pre-marital relations provided certain rules of courtship and matchmaking, which almost to the middle of $20^{\text {th }}$ century were based on Patriarchal foundations.

The most common forms of premarital relations in the old Tuva was oitulash. This night festivities, secret meetings, premarital game, a favorite pastime of youth. These "assemblies" of young crowd sang, as a rule, this was the song contest between the young groups, each of which had its good singers-ringleaders. In song was extolled the love of the faithful, "robust". Song encouraged each other, called to continue the festivities. In oitulash played with 15-16 2030 years. However, the participation married in oitulash was considered reprehensible. At the same time, non-participation in oitulaash young, not married, ignoring his perceived as disrespect to friends-companions: "When the time came to leave, then, can there be talk?" (Zabelina, p.59). Festivities were held in secluded areas, on Islands, at the foot of the mountains. The gathering place as a landmark lit a fire. Met friends. Acquainted unfamiliar. The atmosphere was conducive to intimacy. The initiators of entertainment with erotic overtones (games, jokes, riddles, narratives, etc.) were mostly guys. Such actions were considered as natural and acceptable, and sometimes viewed as an essential component of premarital intercourse.

On oitulaash sometimes find their future wives. In winter time the communication was complicated, however, and in the cold season boys and girls gathered for entertainment. Very in detail describes these traditions N.G. Kurbatskii in his writings, "Tuva holidays: historical and ethnographic study".

According to some pre-revolutionary researchers, for the Tuvans were typical promiscuous sexual relations, generally not allowed the girl to prevent intimacy, and especially to complain to the relatives or to the authorities. So, the exiled Polish revolutionary F.IA. Kohn noted: "the Observance of innocence was not considered a virtue. On the contrary, the girl, who failed to win the favor of men, it is doubtful whether it could be a wife" (Kohn, p.135). The E.K. Iakovleva regarding matrimonial relations reads: "Sexual communication among girls is not considered to be reprehensible and starts very early. The wealthy Soyots adult daughters live in separate yurts, where men lived freely... To premarital relations girls of soyots were indulgent, the child was deemed to belong to his mother's clan and it was honorable, if the child was born to a 16-year-old girl: a girl who lacked suitors long remained to be an old maid" (Iakovleva, p.88).

Distributors of social evils in the field of premarital relations in pre-revolutionary Tuva were lama clergy, as well as feudal lords and their minions, artificially cultivated and hard imposition immoral sexual form of the relationship. In justification of his conduct, they 
spread opinion that the girls would not cohabiting with men cannot give birth, but because such nobody will take to wife. In this regard, one cannot but agree with the opinion S.M. Biche-ool "it would be wrong to these phenomena relate to the norms of customary Tuvinians at all because the above phenomena existed primarily among those Tuvinians who lived near factories, mines, rates of feudal lords and Lam" (Biche-ool, p.101). Later the same F.IA. Kohn noted to generalize phenomenon at all Soyots who lived Ulug-Khem, absolutely unacceptable" (Kohn, p.134).

The adulterous relationships among the Tuvans were condemned. Girls, young men, at least suspected in premarital sexual relations, Tuvinians offensive called "Erzek Kizhi".

In the event of the birth of an illegitimate child, a pregnant woman tried to appear less people on the eyes. But no one pointed, not condemned, fearing existent signs by which who condemns such unfortunate, that remain childless or his children are sick. To the bastard child, as the girl's parents and the surrounding respected. Such children were loved no less than others.

As noted Z.IU. Dorzhu big role in relation to women in the family played her ability to bear children. In the absence of children childless couple took a foster child and relatives. Tuvan family were large. The main burden of child care and education was laid on the woman. Powerless position of women in family and society, its auxiliary role in a peasant farms were predestinated system of upbringing children, different orientations on the education of boys and girls, which was connected with the peculiarities of the social position of men in family and society. From an early age children inspire thought about the superiority of men over women, girls raised submission to the will of the elders, especially my father and brothers. The boy with childhood were brainwashed into believing that he is the owner of the Yurt», continuer. But at the heart of education, both boys and girls lay, above all, work. When the distribution of work between children was strictly followed the principle of the separation of work for boys and girls. Boys joined to the male labor, and the girls had to learn the experience of the mother in the household (Dorzhu, p. 37). It should be noted that the families of stable and divorces were rare due to economic and moral reasons.

Currently in marital and family relations underwent serious changes associated with the transition from the traditional model of the family to modern: simplified family structure, change the system of power and subordination, reduces the importance of the traditional functions of the family - the birth and upbringing of children.

Characteristic changes in the institution of the family is the high level of divorce rates. According to the statistical materials in Russia for every three newly concluded marriage in the year committed two divorce. In the Republic of Tyva at present every third marriage ended in divorce. In addition, the increased number of divorces, and the ratio varies to him - in the public mind it becomes commonplace. Often the young couple believe divorce is quite acceptable exit from a conflict situation, no special effort to maintain the marriage, think about divorce before try to change their behavior and habits for the sake of the family.

One of the major causes of the crisis state of the families is extremely unsatisfactory situation with the preparation of young people for marriage and parental life, which, in turn, is accompanied by inadequate perception and understanding of the personal characteristics of each other, idealization of personal qualities and their subsequent collapse in the consciousness of the person, inability to use psychological mechanism of adaptation and cooperation in the family. Preparation of young people for marriage happens spontaneously, under the influence of mass culture and traditions of the nearest environment, largely lost this role 
of the family, who had successfully coped with this problem. There have been previous attempts to solve this problem with the introduction of parental education and the school course «Ethics and psychology of family life», but previous experience was successful. In modern society, neither in school nor in the University education in General there are no programs for training of students in the family-marital relations.

To date, no work, containing a complete study of the problem of preparation of youth for family life, insufficiently studied area, analyzing the various aspects of pre-marital behavior of youth, almost no research on the development of methodologies for conducting classes forming successful family and marital relationships. Thus, the actual contradiction between the objective value to society of a strong, high-grade family with children and the lack of value attitude to the marriage of the younger generations; between the growing needs of society in the preparation of the studying youth for family life and traditional educational practice not provide for such training.

The problem of preparation of youth for family-marital relations are reflected in the works of many Russian and foreign authors. One of the first attempts to determine the nature of marriage and family relations belongs to the famous ancient Greeks Plato and Herodotus.

In foreign social psychology maximum widespread theories, considering the "technology" of the choice of spouse: an instrumental theory of selection of the spouses by R. Senters; "theory filters" by A. Kerggoff and K. Davis, where young people go through a series of filters, gradually eliminating many possible partners and narrowing individual choice. Pie's theory of love A. Flight explains the mechanism of choice of the partner in life through the implementation of four successive interconnected processes: the establishment of the relationship, self-revelation, the formation of mutual dependence, realization of the basic needs. The study of conditions and factors of premarital behaviour, contributing to the success of future marriage, devoted their work sociologists A.G. Kharchev and A.S. Matskovsky, who argue that the character of the future marriage defines what is each of the entities forming the marriage relationship; L.I. Savinov quite examines in detail the specifics and dynamism of pre-marital behaviour, revealing various theories of choice of marriage partner; T.A. Gurko describes the influence of pre-marital behavior on the stability of a young family. The author considers such factors as the duration acquaintances, the presence of shared Hobbies and interests, installation and expectations about family life; V.M. Tseluyko deals with the psychological aspects of premarital behavior of youth, influencing on the further stability of a young family.

Issues of sex education for young people paid much attention to J. J. Rousseau, I.G. Pestalozzi. The problem of family and premarital education of the young generation is reflected in the works of the prominent teachers of the past. The most significant works belong to IA. A. Komensky, YA. Korchak, L.N. Tolstoy, K.D. Ushinsky and others. This problem was considered by such famous teachers as N.K. Krupskaya, A.S. Makarenko, V.A. Sukhomlinsky. They called for the use of rich pedagogical heritage of the people in preparing young people for marriage and family life, paid great attention to family relations as a key factor of education of the family man, underlined the importance of the family in society. Among the modern researchers can be noted: the height of the Reich in the work of the «Sexual revolution» covers the halfheartedness, timidity and inconsistency of sex education, by now, speaking from the preaching of the sexual revolution and the abolition of the requirement of "repressive morality". T.F. Zubkov and N.V. Timoshina also express the 
idea about joint participation in sexual education of children, teenagers and youth, parents, and educational institutions. The authors give the sexual education of the state value, and hence a large role in its implementation is given of the state youth policy, one of whose goals is to educate young people about family planning. I.V. Grebennikov in "Basics of family life" reveals the essence of readiness for marriage and family life, outlining the methodology of preparation of pupils to family life. I.V. Dubrovina, E.I.Zritneva, T.I. Yufereva analyze the factors influencing the formation of the readiness for family life. T.A. Kulikova expresses the idea about the need for education of the future family man, including sex education, introduction to the economy of the family, the formation of ideas about the family.

However, it is worth noting that the most actively this problem has been considered in the 70-90-ies of the last century. Wherefore sources, fully reveal the problem of preparing young people for family life in modern society is clearly not enough. The situation is similar with regional research. Although the modern Tuva historiography there are a number of works, whose authors some problems of the status of women in family and society in the context of more General issues. Traditional forms of marriage and family of the Tuvans, wedding rites, including premarital relations, are considered in the thesis S.M. Biche-ool «Traditional marriage and family relations of the Tuvan people (and their changes in connection with the socialist transformation of Tuva».

In G.A. Zabelin's monograph "Women of Tuva in the family and society in the first half of the $20^{\text {th }}$ century" the author analyzes the problems of emancipation of women in feudal Tuva and their role in the TPR in the economic, political and cultural development of the Republic demonstrated a non-capitalistic path to socialism.
Different genres folklore material, as a manifestation of the unique culture of the Tuvan people assembled in the monograph by G.N. Kurbatsky "Tuvinians in their folklore". It reflected the family household units Tuvan ethnic group associated with marriage: matchmaking, marriage, relations of the spouses, the position of women.

Of interest here is article by Z.I. Dorzhu "Gender as a problem of ecological and secure the sustainable development of society", "About preparation of youth for family life", "Fertility in Tuva: present and future". Thus, the issues of preparation of youth for family marriage relationship highlights the many domestic and foreign authors. However, insufficiently studied are still many features of pre-marital behavior of modern youth and the problems of its preparation for marriage. Out of sight scientists are diverse factors influencing the formation of the family and marriage relations the peculiarities of the preparation of youth for family life in the conditions of transformation of the Russian society. There is no single, comprehensive program aimed at the development of the younger generations of responsible attitude to family and marriage.

According to scientists, prenuptial behavior, determined by biological, psychological, sociocultural, socio-demographic characteristics of the person aimed at the choice of marriage partner and satisfaction of needs in marriage, the family, his attitude to family values, the result of which, depending on a concrete situation, can be: marry and found a family, to create a family out of wedlock, as well as the renunciation of marriage and creating a family (Dorzhu 6, p.46).

«Gender specific pre-marital behavior is the social, cultural and psychological peculiarities in the behavior of women and men, aimed at satisfaction of needs in marriage and family, the formation of ideas about the nature 
of future marriage, relationships to family values, corresponding to the social norms and expectations, which are typical for men or for women.

Installation and value orientation of premarital behavior of young people, the idea of marriage and the family are not spontaneously but within a certain time and under the influence of various social institutions: original culture of the society, the parents ' family, then schools, universities offer education and training to labor and socio-political life. A special factor influencing the prenuptial behavior of students, acts University landscape. Under its influence among the youth formed the progressive trends of gender-specific pre-marital behavior: equality between boys and girls, tolerant attitude to male and female qualities, social activity in dealing with the opposite sex, well-defined independent stand on the issue of creation of family and marriage.

A certain impact is produced by media, peers and senior colleagues etc. All of this together broadens the mind and the range of interests of a personality, her (his) views on the world, on marriage and the family in particular. Thus, it is impossible to distinguish which one is more important or more powerful. However, no social institution alone can be considered fully responsible for shaping the views of young people about the nature of future marriage, relationships to family values, the result of pre-marital behavior - the decision to get married, create a family or refuse to make such a decision.

Over the past decade in Tuva has changed significantly prenuptial behavior of young people: they stopped to traditional attitudes to premarital chastity. Today the proportion of floors from 14 to 30 years in Tuva is $48.6 \%$ of men and $51.0 \%$ of women. For comparison, in 2007, $48.7 \%$ and $51.3 \%$ of (The demographic situation in the Republic of Tyva, p.51). Disproportion associated with overweight female population over the male, though a little figure, reduces the likelihood of marriage for each young woman that is negatively affecting the demographic situation.

In 2007-2008 we have conducted a survey among students in Tuvan state University, where considered marriage and family installation and pre-marital behavior of boys and girls, their views of marriage and family. Were interviewed 220 people, the percentage of boys and girls, as well as the Tuvan people (and Russians in line with the General ratio of students at this University and was $60 \%$ female and $40 \%$ male. The ratio of Russian and Tuvan amounted to two-thirds of the representatives of the titular nation and one-third of Russians, which reflects the national trend. In the study of gender-specific pre-marital behavior, we tried to consider all the factors influencing the family the socio-economic conditions, family structure, its spiritual foundations. The obtained data allows to estimate really prenuptial behavior of young people and the state of the family in Tuva, get information about the processes occurring in it.

We started to survey the views of young people about the period of courtship, the essence of premarital sexual relations. Almost $70 \%$ of students of both sexes allow pre-marital sexual experience. Meanwhile, among the $15 \%$ of essentially non-premarital sexual relationship, women are 4 times more than men. Of great interest are the motives of premarital sexual relations. $24 \%$ of respondents believe that premarital sexual relationship help «get to know each other», $18 \%$ believe it is a "private matter», $17.5 \%$ is «a continuation of the senses, to $15 \%$ is «the need to satisfy the sexual needs» and $5.4 \%$ of «the need to gain experience».

More than $20 \%$ of students of both sexes difficult to substantiate the need for a sexual experience. It is obvious that the moral-ethical position of youth differs sharply from the 
installations of the older generations. Young people living in the capital, chose the prestigious profession, no prohibitive norms mandating premarital chastity. Our survey showed that the average age of beginning sexual life in Tuvan students is slightly more than 17 years. However, with all the looseness of behavior of young people, one-third of the female students, by the third year, that is about 19 or 20 years, still have no sexual experience. When the mass of match of men's and women's assessments of pre-marital behavior, there are serious differences in life purpose and the mood of girls and boys. Answers girls often reflect a conflict between standards and actual life situations. So, most students would prefer to premarital relationship only with your future spouse, while the boys had such a setup. It is obvious that for many young men sex is not connected with being responsible for the fate of a woman.

However, the large differences in attitudes and sexual behavior of youth compared with older generations, cannot be regarded as moral decadence, universal turpitude, the death of family values. Such assessments would be superficial. When the whole evolution of the relations between the sexes in the direction of democracy, tradition encourages young people to marry for the sake of observance of the customs. In Tuva remains resistant orientation of society to the marriage. Students indicated that they very important "to have a husband (wife)" (57,4 \%), "have children" (86,3\%). These data suggest that traditional values remain the priority for today's youth, but some changes are still observed. So, for example, the attitude to the registered marriage differs from attitudes to the problem of the older generation. Only for $41.6 \%$ of young people registered marriage is important, but for 40.2 percent of it is not important. About $70 \%$ of young people would like to live separately from their parents, which entail both positive and negative moments. On the one hand, the young family before acquires independence, responsibility, easier process of adaptation of young spouses to each other. But, on the other hand, young families lose often systematic assistance to parents that they need, especially in the period of the birth of the child. Often violated in this case and constant communication with my grandparents, which solitarily influences on the grandchildren. The lack of contacts violates the continuity of generations, when the children do not even know their close relatives. The harsh reality was the emergence of a lonely abandoned elderly people. In connection with growth of personal autonomy young family probably will continue to develop in this direction. Again, the task is to mitigate the negative effects of this process.

Changes and age of the marriage, and the model of traditional marriage. In the Republic from year to year grows the birth of children out of wedlock. In 2002 born 5727 children out of the registered marriage came to light 3553 child (62\% of the total number of births as against $41 \%$ in 1992) (8, p. 7). In 2006, born 5950 children, out of the registered marriage came to light 4033 baby, that was the whole country in General $67,8 \%$, of them in the countryside was born 2292 child or 56.8 \%. In 2007 in the Republic was born 7446 children, from the bottom $61.1 \%$ of all births were children of single mothers $(9$, p.5). Out-ofwedlock birth rate in the Republic continues at a high level in the next years. At the same time in Tuva there is a significant growth of illegitimate children born to young mothers. Not a secret, that poverty in the Republic among other things connected with very low border of reproductive age. In 2007, mothers up to 17 years old were born 184 children, from them at the age of 15 years and younger are 13 children (in 2000 - 106 and 12 respectively) (The demographic situation in the Republic of Tyva, p. 6). The most frequent 
extramarital birth of the youngest (under 17 years) women in rural areas: every third child born to a mother that age, was illegitimate. This growth can be explained by the fact that in recent years, especially in rural areas, many families have lost permanent sources of income, unemployment is high, and the children's allowance for them is one of the main income. That is partly situation provokes the state itself: the sum of pay for more if a woman alone. Women began to give birth, without being married. So, during the intercensal period in Tuva by $34.8 \%$ increase in the number of persons never married (The demographic situation in the Republic of Tyva, p. 8). The greatest distribution parent families received among 15-19 year-olds and women up to 35 years and older distributed among all strata of the urban population. Apparently, the situation when traditional marriage was the only permissible form of joint life of the Tuvan people, rooted in the past.

The society was tolerant as for single mothers $(35,6 \%)$, and to divorce in families with minor children $(54,9 \%)$. Divorce ceases to be scary, and public opinion has been perceived as a phenomenon is a normal and even beneficial in some situations. Among the most common causes of this process: alcoholism and roughness of the spouses, the inability to adapt, one spouse ceased to love another. All this is ultimately a consequence of the fact that in modern conditions of a young woman is much more complicated than before, manages to combine motherhood, study or work. On the other hand, it also became a direct consequence of the economic independence, the high educational level of women, their unwillingness to tolerate a bad marriage. She too sure to raise children alone. Therefore, more and more often incomplete families (The demographic situation in the Republic of Tyva, p.37).

Increasing in the Republic received extramarital sexual relations between when a married couple, living together and having a common household, don't register their marriage or register it when already had a child. Public opinion in relation to cohabitation, in contrast to the recent past, tolerant, that does not give grounds to speak about a decrease in their number in the future. The birth rate in the Republic has maintained positive dynamics, although the trend of reducing the number of large families. More than half of students of both sexes believe that marriage should be with their peers in the range from 21 to 25 years. Entering into family life, youth wants to get rid of parental care (19\%), looking for it, first of all, the scope for the manifestation of his independence (48\%), waiting for moral support and understanding (22\%). Attitudes towards the future of the parenthood is a strength at $28 \%$, the rest of the expectations associated with the advent of the child or does not match or do not correspond to real conditions.

Such new phenomena that have been in our lives as sex persons of the same sex and demonstration of sex scenes in movies is perceived negatively in the first case $78,9 \%$, in the second $67,4 \%$ of the students. The idea of polygamy is also not supported. Against it are 87,4 \% of girls and $73.3 \%$ of boys. These data suggest that the strength of the structure, conservative look on universal values. The presence of the opinion that «to live in an urban environment for me is very important» $(59,4 \%)$ and «to have their cattle - not important» $(41,6 \%)$ of students reflect the fact that the outflow of the young population from rural areas due to weak infrastructure development and the problem of employment in rural areas. It also confirms the fact of a weakening of the traditional way of life for young people.

Of particular importance for the formation of moral and psychological preparedness of young people for marriage and future family life has a parent family. It forms the future spouses and the parents of moral and cultural norms, 
stereotypes communication and behavior, ideas about the family structure, corresponding to the male and female patterns of behavior. However, according to a survey, there is a reduction in the regulatory role of the family in respect of premarital behavior of young people. Family life of parents is a sample only $28 \%$ of boys and girls. Only one third of the adult children would like to be like their parents. According to our results, more than $40 \%$ students of both sexes intend to make your choice of a spouse, neglecting the opinion of the parents.

Studies greatly facilitates the process of marital selection of students, it is the University became one of the main potential sites for Dating (32,5\% of the young men, $29,07 \%$ of girls). Education and independence is the primary goals not only for boys, but for girls. Observed erase the traditional double standard in добрачном behavior (what can be men, not women). Most students surveyed $(60 \%)$ are focused on family, friends, interesting job, a good education, leisure. Girl a few dominate the orientations of the marriage. Despite the formation of the new views on family and pre-marital behavior in society is still strong enough thousand-year experience of family traditions.

And only a small part of young people (14\%) have set themselves the wide range of goals in life and believe that they can achieve at least a part of them. They want to create their own business, to get access to power, to make a career. Thus, the complexity of the situation for the process of creating a family according to the described above evaluation criteria premarital relations consists, among other reasons in the peculiarities of the life expectancy of the population of the Republic. Have undergone significant changes since the most important moral values. But even in the conditions of deep social crisis, as many years ago, young people focuses on love, evaluating it as its primary motive the creation a family.
However, the girls put calculation on the second place after love. Boys of calculation of marriage takes the last place, and the desire to create family home occupies the second place after the motive of "love", in women - the fourth. It can be stated that the motivation for marriage has not changed substantially over recent years. A new situation is more pronounced motive calculation. Very common requirements to his beloved. Neither boys nor girls do not put the external appeal on the first place. This once again confirms the Tuvan saying "Charazhynga Shay khaiydyrar eves, chazhynga a't orteer eves" tea is not to cook on beauty, not the horse tied to a glory, which resonates with the Russian proverb "with beauty's drink, there would be a person". Boys of this sign is on the 4th place, the girls on the 6-m Students, both boys and girls, put forward to the future spouse, first of all, requirements such as mind and intelligence. Then there are universal moral values: kindness, decency, reliability, loyalty and love for children, loyalty to family, modesty, patience. Students of both sexes consider mandatory quality spouses ability to mutual understanding.

Most students believe that all the difficulties emerging in the relationship in the premarital period will disappear after marriage. This is expressed, first of all, in the fact that young people exaggerate ennobling influence of love. But these difficulties remain and play a negative role in family life until they are resolved positively and termination of marriage. However, a growing number of young people tend to rationalize the marital choice. The question of what is better guided in marriage, defenders of marriage based on feelings, was more than half $-59 \%$; in favor of marriage based on the calculation, expressed $25 \%$, which, in our opinion, a lot.

In connection with the policy of official internationalism in Soviet times were encouraged inter-ethnic marriages. They accounted for $15 \%$ of the total number of marriages. Today, 
this process has stalled in connection with the aggravation of interethnic relations. This suggests that the growth of mixed marriages in the foreseeable future is not expected. The vast number of young people (75\%), even considering themselves internationalists, fear should obey the foreign customs and wish to enter into marriage with a representative of his nationality.

Thus, the level of preparedness of young people for marriage is extremely low. It is not rational and emotional approach to marriage, overvalued romanticism, absence of the major psychological and household skills. Having overestimated, idealized concepts of marriage, the young couple quickly feel frustrated. Difficulties of family life are transferred to the identity of the wife, with whom it is difficult to get along with.

The main problems faced by the young family: not in housing, low wages. Thus, many young families permanently or from time to time experienced financial difficulties. And these problems are one of the reasons leading to family breakdown and divorce. A survey on this issue showed the following picture: respondents believe that the future of children should keep a couple from divorce $(62,4 \%)$, should keep a sense of responsibility for their own future $-16,4 \%$.

Betrayal is one of the first places among the subjective causes of divorce. Assuming premarital sexual relations as unconditional modern norm, students of both sexes in its most sharply negative attitude to adultery. Women that do not allow treason fundamentally, evaluate it as a betrayal. Many of the respondents believe that the random physical cheating should not destroy the marriage. The diversity of opinion on the most complicated problems of family relations is not high ethical norm aimed at fidelity as the most important family values. Students of both sexes consider that a serious reason for divorce is the exhaustion of the senses. This opinion is consistent with the main motive of marriage - love. We can say with confidence that the public opinion expressed by the absolute majority of the respondents, evaluates a marriage without love as immoral, and its absence is defined as a serious reason for dissolution of the marriage.

Young people agree that the main family difficulties are of psychological character: misunderstanding, intolerance, irritability, inattention, and fatigue from each other. An important condition for the stability of marriage young people called coincidence educational and intellectual level of the spouses. Looking ahead to his family future, students represent the Union of loving, faithful spouses, caring caregivers of children. A man should earn well and completely financially provide for the family, children's upbringing should not change his wife, not to be passive and indifferent to the family, the household, not be a drunkard, not to be greedy, lazy, and selfish, have a high sexual performance. Modern woman must not: be черства, rough and aggressive with family, modify husband, humiliate and constantly to «cut» a husband and children to interfere in the Affairs of the family of a daughter or son.

According to the study, the most important value for young people is the family. Young people are sufficiently aware of the so-called «social package», which supports young families. $42.6 \%$ of the respondents number of young families answered that they know and use. Own accommodation is a fundamental condition for a young family. So, $72.3 \%$ of the respondents gave an answer that should be preferential loans for the purchase of housing. Support of young families in addressing the housing issue will be the basis of stable conditions of life for the most active part of the population. In 2008 the state support of young families was carried out in the framework of the sub-program "Provision of housing of young families", which is part of the Federal target program "Housing" for 
2002 - 2010. The main purpose of the subroutine is to provide state support in solving the housing problems of young families in need of better housing conditions.

Within the mentioned subroutines in 2008, 62 young families of the Republic received subsidies, 206 young families provided with housing on the Federal target program «Development of the village till 2010». In 2007, young families to 35 years granted 98 mortgage loan, in 2008 - 58, unfortunately, in the next years there is a decrease in the granting of loans due to the growth of housing prices [Morozov, p. 10). There has also been a deterioration in the financial status of families due to job loss, reduction of wages, the rising cost of living in General and etc. All young families to improve their living conditions, to continue higher education, systematically organize informative family leisure, sports.

Such restraining or otherwise mitigating factors as the revival of spiritually-religious life, traditions, customs and ceremonies, the younger generation does not yet have an adequately its beneficial effects for a number of reasons. The spiritual connection $37.7 \%$ of respondents with the representatives of older generations is limited only by the circulation of the former to the latter for advice. Their contact with traditional culture, past the country and the Republic is limited to the celebration of important dates (33\%). Only $27.4 \%$ of respondents observe customs and traditions, only one-fifth ( 20.2 percent) of children in respect for elders, the values of the national history and culture. No conscious approach of youth to national culture, customs and traditions of its people.

Thus, the model of pre-marital behavior and the roles which are attributed to men and women in добрачном behavior of today are the product of evolution of family and marital relations in General, the result of the natural and social selection, which were reinforced with those norms and rules in the relationship between the sexes that are better adapted to social culture. If in the past, the choice of marriage partner defined interests kind of family and youth, submitted to the stereotypes accepted in society, today it is largely free in their behavior. Sphere of communication today's young people is becoming more differentiated and selective. The value orientations of young men and girls are such that love and sexual satisfaction are of value in themselves and do not always lead to marriage. As a progressive and the most active part of the youth, the students offers particular opportunities for realization of their attitudes and needs in the area of pre-marital behavior, largely contribute to the change of the social Institute and operate on gender-sensitive, that is, the ideas about what should be pre-marital behavior of men and women. This factor is very important for the prediction of changes of the family. It is the pre-marital period that leads to successes and failures that in the future may enhance marital and family relations. It is therefore necessary to carry out purposeful and systematic preparation of young people for marriage and family life, which can be carried out by professionals in the field of pedagogy, sexology, social work, psychology. Special attention in the provision of training of young people for marriage and family life should be paid to gender consideration, where also there is an important connection of theory with practice, with real life. Forms of work of the specialists involved in the preparation of young people for marriage and family life can be different. This training lectures and seminars on the problems of the family and premarital training, conferences, exhibitions, scientific and artistic literature on the problem, the discussion of books and articles from periodicals, viewing and analysis of documentary films, the use of training, tests, organization of presentations 
of large families married couples and spouses who celebrated the «Golden jubilee» etc. In solving the problems of young people should be interested not only young people, but also public authorities and society. This is due primarily to the high importance of this demographic group for development and the future of the family, society and the state.

\section{References}

1. The demographic situation in the Republic of Tyva (Analytical review). Territorial body of Federal service of state statistics in the Republic of Tyva. Kyzyl, 2010. 59 p.

2. Golod, S.I. State and prospects of development of the family. St. Petersburg, St. Petersburg branch of the RAS, 1994.

3. Grebennikov, N.V. Basics of family life. Moscow, 1991. 158 p.

4. Gurko, T.A. Marriage and parenthood in Russia. Moscow, Institute of sociology RAS, 2008.

5. Dorzhu, Z.IU. Gendernyi faktor kak problema ekologo-bezopasnogo ustoichivogo razvitia obshchestva. Proc. 5th Int. Symp. "Sustainable development of small peoples of Central Asia and steppe ecosystems". Volume 2. Kyzyl, 1997, p. 328-332.

6. Dorzhu, Z.IU. About preparing young people for family life. Materials of the scientificpractical conference "Children of Tuva on the threshold of XXI century". Kyzyl, 1999, p. 55-57.

7. Dorzhu, Z.IU. The birth rate in Tuva: the present and the future Materials of the International scientifically-practical conference "The ethno-social processes in Inner Asia". Issue 9, Semei, p. 34-38.

8. Dorzhu, Z.IU. Tuvan family: trends of its activity The Omsk scientific Herald. A Series Of Society. History. Modernity. №1 (95), 2011. 223 p.

9. Zabelina, G.A. Women Tuva in the family and society in the first half of XX century. Kyzyl, TuvTIKOPR SB RAS, 2010. 120 p.

10. Zubkova, T.S. The organization and content of work on social protection of women, children and family. Moscow, Academy, 2004. 224 p.

11. Kovalev, S.V. Preparing high school students for family life. Moscow, 1991.

12. Kohn, I.S. Sexual culture in Russia. Strawberry on the birch 2-e Izd., Rev., extra. Moscow, iris-press, 2005. 448 p.

13. Kohn, F. IA. Expedition in Soiotia. Moscow, 1934. 293 p.

14. Kurbatskii, G.N. The Tuvinians in its folklore (historical-ethnographic aspects of Tuvan folk. Kyzyl, Tuvan publishing house, 2001. 464 p.

15. Morozov, P. A. Situation of youth in the Republic of Tyva in 2008. Report of the Minister of education, science and youth policy. Kyzyl, 2009. 20 p.

16. Novikova, E.N. Gendernaia spetsifika dobrachnogo povedenia molodezhi. Formation and development of social work as a science: collection of Art. Saransk: Publishing house of the Mordovian University, 2006, p. 45-48.

17. Sukhomlinsky, V.A. Wisdom of parental love. Moscow, 1988. 304 p.

18. Tymoshenko, L.N. Education high school. Moscow, Education, 1990. 190 p. 


\title{
Гендерный подход в подготовке тувинской молодежи к семейной жизни
}

\author{
А.В. Седен \\ Тувинский государственный университет \\ Россия, 667000, Кьзыл, ул. Ленина, 36
}

\begin{abstract}
Тувиниы считали брак обязательным для каждого человека, внебрачные отношения не одобрялись. В Туве традиционно семьи были большими, разводы были редки по экономическим и моральным причинам. В настоящее время происходят серьезные изменения. Наблюдается все большее число разводов, изменилось и отношение к ним - в общественном сознании это воспринимается как обычное явление. Меняется добрачное поведение молодежи: не работают традииионные установки на добрачное иеломудрие. Когда вся эволюиия отношений между полами движется в направлении демократии, традииии вдохновляют молодых людей на брак ради соблюдения обычаев. В Туве остается стабильной ориентация на брак; для студентов очень важно "иметь мужа (жену)" (57,4\%) , “иметь детей” ( 86,3 \%). Около 70 \% молодых людей хотели бы жить отдельно от родителей, что влечет за собой как положительные, так и отрицательные моменты. С одной стороны, молодая семья самостоятельно несет ответственность за брак, легче проходят процессы адаптации молодых супругов друг к другу. Но, с другой стороны, молодая семья лишается систематической помощи родителей, в которой они нуждаются, особенно в период рождения ребенка. Нарушаются в этом случае и постоянные связи с дедушками и бабушками, что не лучшим образом сказывается на воспитании внуков. Наблюдается изменение возраста вступления в брак и самой модели традиционного брака. Участились случаи рождения детей вне брака. Распространено семейное сожительство. Рождаемость в республике продолжает положительную динамику, хотя наблюдается сокращение числа многодетных семей. Более половины студентов обоих полов считают, что заключать брак нужно со своими сверстниками в возрасте от 21 до 25 лет.
\end{abstract}

Ключевые слова: брак, семья, национальная психология, Тува.

Научная специальность: 07.00.00 - исторические науки. 